\title{
O posto de honRA de LuIZ GAMA
}

FERREIRA, Ligia Fonseca (org.). Lições de resistência: artigos de Luiz Gama na imprensa de São Paulo e do Rio de Janeiro. São Paulo: Edições SESC, 2020. 392 p.

Desde o século XIX, Luiz Gama insiste em nos provocar com Lições de resistência. Gama foi escravizado, conquistou a alforria, foi reconhecido como intelectual conceituado já no seu tempo, enquanto se tornava um dos principais personagens do movimento abolicionista. As suas ideias e o seu empenho como jornalista e rábula na defesa da liberdade dos escravizados o transformaram numa referência incontornável da luta pela igualdade racial ainda nos dias de hoje. Em tempos de aprofundamento das desigualdades, Luiz Gama, negro, abolicionista e republicano continua a ser um farol para quem aspira por justiça e, por isso, mantém-se entre os autores brasileiros mais lidos, seja como literato ou como ativista engajado no campo do direito.
Lígia Fonseca nos traz uma oportuna interpretação dessas Lições de resistência, sublinhando-as com tinta preta. Há mais de vinte anos ela tem se ocupado da tarefa de analisar e divulgar a produção literária de Gama. Em 2020, quando resistir definiu a condição de existência humana, a autora nos presenteou com a edição de uma coleção de textos dele, alguns já bem conhecidos e outros ainda inéditos. O livro reúne, pois, artigos e cartas publicados na imprensa, mas também correspondência pessoal de Luiz Gama com seus partidários, amigos e parentes.

O primor metodológico com que Fonseca organizou este livro é, por si mesmo, uma lição sobre como lidar com fontes dessa natureza. Como está indicado de maneira tímida na nota 
sobre a edição e fica evidenciado ao longo do livro, a atenção conferida à cronologia ressalta as estratégias narrativas e de ação para a luta antiescravista liderada por Luiz Gama. Com os textos dispostos na sequência dos acontecimentos, notamos não apenas o sentido político de cada um deles, mas a cadência da ofensiva do abolicionista diante dos desafios que se acirravam à medida que as disputas se aprofundavam no parlamento, tribunais e redações dos jornais, entre as décadas de 1860 e início nos anos 1880. Por essa razão, é relevante a informação dada por Fonseca de que alguns dos textos aqui reunidos foram originalmente publicados em jornais paulistanos e reproduzidos em seguida nas folhas cariocas. Luiz Gama reconhecia as oportunidades, identificando os momentos-chave para fazer valer as "revoluções de liberdade" que tinha a Corte como principal cenário para as decisões governamentais no Império.

Se as Lições forem lidas encadeadas, podemos perceber 0 crescimento dos debates e as tentativas sórdidas para frear a locomotiva abolicionista. Luiz Gama costumava esquentar a temperatura política, mas, quando convinha, estrategicamente, a abrandava. Se a circunstância lhe parecia favorável, ele investia na imprensa como tribuna para o convencimento de corações mais suscetíveis à “causa dos escravos”. Nessas ocasiões os escravizados eram definidos como “irmãos desvalidos”, “pobres infelizes”, "vítimas do hediondo crime" - vocabulário que poderia capturar a opinião pública, retórica apropriada para sensibilizar leitores de vários tempos. E aqui surge mais um primor dessa edição. A competência de Fonseca nos estudos literários e linguísticos a fez preservar os recursos tipográficos utilizados nos textos de Gama, sinalizando para ficarmos mais atentos a certas informações e argumentos que ele procurava ressaltar em meio às letras miúdas dos jornais da época. Deste modo, essa edição nos ajuda a perceber o quanto foi fundamental a ação do jornalista para o sucesso do rábula Luiz Gama, e vice-versa.

Este é um livro sobre o cálculo político de um ativista negro. Gama é famoso pelo modo corajoso com que enfrentava homens poderosos, fossem eles senhores, juristas ou palacianos. Em Lições de resistência, o leitor 
encontrará incontáveis alusões ao contrato imoral firmado entre os operadores do direito e os donos do capital, com o único propósito de dar alguma sobrevida ao escravismo. No vocabulário de Gama, as elites brasileiras produziam "usurpadores imorais" da lei, irmanados na tarefa de conservar a velha ordem. Como ele registrou, a magistratura era "o braço de ferro dos senhores” (p. 304), e ele não se eximia de nomear e expor ao julgamento público aqueles que deveriam julgar com isenção os processos pertinentes à liberdade dos escravizados. As páginas desse livro nos apresentam a doutores que distorciam leis, contrariavam trâmites, cometiam "assaltos jurídicos” por ignorância ou convicção conservadora. A certeza de que entre os magistrados estavam muitos agentes da imoralidade e da ilegalidade o levava a desafiá-los: "processe-me, ou mande processar-me; cumpra o seu dever, porque eu saberei manter ileso o meu direito” (p. 154).

O leitor, mesmo ciente da metodologia de Fonseca, também pode apreender as Lições salteando as páginas, abrindo o livro aleatoriamente, para encontrar um militante vulnerável pela sua condição sociorracial.
Ainda assim, Luiz Gama não perdia a oportunidade para reafirmar a validade da sua luta, nem as credenciais que o habilitavam a interferir nos destinos da nação. Negro, sem título de bacharel e na linha de frente da luta antiescravista, Gama municiava-se de vasto saber jurídico para marcar posição, realçar a pertinência das suas bandeiras e proteger-se dos inimigos abastados. Quando foi ameaçado de morte em 1870, ele demonstrou ter consciência do seu papel político publicizando o risco e pondo a questão nos seguintes termos: "Façam o que entenderem. $\mathrm{Eu}$ estou no meu posto de honra" (p. 172). As desavenças, portanto, diziam respeito a algo nacional e a opinião pública deveria tomar conhecimento do perigo ao qual ele estava exposto por defender uma mudança radical na sociedade em que vivia.

Há aqui também correspondência privada. São cartas que narram a imprescindível rede de afeto e colaboração política na qual ele se amparava. Os inimigos eram poderosos, mas ele tinha "amigos em toda parte" (p. 172). As cartas mais emocionantes são as trocadas com Lucio de Menezes, parceiro no front abolicionista, amigo que compartilhava da sua vida privada 
e seu primeiro biógrafo. Enquanto as lemos vai se desenhando o território por onde circulavam as ideias e ações de Gama. Fosse nas redações de jornais como o Diabo Coxo, fundado por ele em sociedade com Angelo Agostini, em 1864, fosse nas articulações do Club Radical Paulistano, entre os maçons da Casa América, lá estava Luiz Gama.

Para nos guiar por esses ambientes e contextos, Fonseca nos oferece uma excelente introdução e muitas e esclarecedoras notas de rodapé. Recomendo ao leitor que desfrute delas com o mesmo afinco dedicado aos textos de Luiz Gama. Nas notas aprende-se sobre os embates, dilemas e assuntos mais palpitantes a mover a pena do abolicionista. O que torna descabido o apelo de Fonseca à benevolência e compreensão dos leitores quanto ao tamanho que elas ocupam nesta edição. De fato, seria "impossível e leviano renunciar" (p. 81) a elas.
Por fim, cabe salientar o leque de temas que vão sendo distribuídos por Gama nestas Lições, também por isso, tornando-as atualíssimas: a separação entre Igreja e Estado para que seja garantida no país a "liberdade de consciência” (p. 107); a incessante construção da democracia constitucional; os compromissos políticos e privados dos magistrados em detrimento do interesse público; valores republicanos; e, é óbvio, a liberdade negra e a igualdade racial. Ao revirar as últimas páginas é provável que o leitor, tal como me ocorreu, se sinta perplexo diante da atualidade delas. Certamente o engajamento e a lucidez política de Gama podem expandir o futuro da nação através dos sonhos acalentados por ele. Fonseca nos apresenta nestas páginas o Luiz Gama que atravessa o tempo para nos dizer, entre a desolação com o cenário nacional e um rasgo de rebeldia, que "Como os barões da idade média, hão de cair os landlords [senhores]” (p. 307).

\section{Wlamyra Albuquerque (D)}

Universidade Federal da Bahia 